\title{
Bilateral Linear Lichen Planus Pigmentosus Associated with Hepatitis C Virus Infection
}

\author{
Vasanop Vachiramon Poonkiat Suchonwanit \\ Kunlawat Thadanipon \\ Division of Dermatology, Department of Medicine, Ramathibodi Hospital, Mahidol \\ University, Bangkok, Thailand
}

\section{Key Words}

Lichen planus · Lichen planus pigmentosus · Hepatitis $C$

\begin{abstract}
Lichen planus pigmentosus is a rare subtype of lichen planus. We report a first case of lichen planus pigmentosus with bilateral linear distribution associated with hepatitis $C$ virus infection. The lesion was improved after sun avoidance and treatment of hepatitis $C$ virus infection with a combination of interferon and ribavirin. This case stresses the importance of screening for hepatitis $\mathrm{C}$ virus infection as lichen planus pigmentosus can be an associated condition.
\end{abstract}

\section{Introduction}

Lichen planus pigmentosus has been described as a condition of unknown etiology which clinically differs from the classic lichen planus by exhibiting dark brown macules and/or papules, mottled or reticulated hyperpigmentation and a longer clinical course. The most common sites of involvement are the face and neck and the flexural folds $[1,2]$. The most common pattern of pigmentation is diffuse, whereas less common patterns include reticular, blotchy, unilateral linear and perifollicular patterns. However, there has been no previous report of lichen planus pigmentosus with bilateral linear distribution. We report a first case of lichen planus pigmentosus with bilateral linear distribution associated with hepatitis $C$ virus infection.

\section{Case Report}

A 33-year-old male presented with itchy brown-gray patches which first appeared on the dorsum of both hands and then spread proximally to both forearms and arms 2 years before consultation. There was no history of preceding inflammatory papules or scaly eruptions. He had no history of contact with 
any chemicals, plants, or perfumes and was not taking any medications. He had no known underlying disease. There was no family history of similar skin lesions.

Physical examination showed bilateral linear streaks of brown-gray patches with violaceous hue on both arms and forearms (fig. 1, fig. 2). There was no lesion on oral mucosa or nails. A skin biopsy was obtained from the right forearm and the left arm and stained with hematoxylin-eosin. It consisted of compact orthokeratosis, epidermal atrophy and focal hypergranulosis with vacuolar alteration of the basal cell layer and band-like infiltration of lymphocytes and melanophages with incontinence of pigment (fig. 3 ). Routine laboratory findings were normal, except for an elevation of serum aspartate aminotransferase and serum alanine aminotransferase. The serology for hepatitis $C$ virus was positive, while the serology for hepatitis B virus was negative. The lesion improved after sun avoidance and treatment of hepatitis $\mathrm{C}$ virus infection with a combination of interferon and ribavirin.

\section{Discussion}

Lichen planus pigmentosus clinically differs from the classic lichen planus by exhibiting dark brown macules and/or papules, mottled or reticulated hyperpigmentation and a longer clinical course without scalp, nail, or mucosal involvement. It is most common in sun-exposed areas such as the face and neck and the flexural folds, including axillary, inguinal, and submammary regions [1]. Some authors observed a striking predominance of lesions in intertriginous locations, among which axillae are the most common; thus, they proposed the designation lichen planus pigmentosus inversus [2]. The most common pattern of pigmentation is diffuse, whereas less common patterns include reticular, blotchy, unilateral linear and perifollicular patterns [3]. The characteristic histopathological findings are atrophic epidermis with vacuolar alteration of the basal cell layer, and scarce lymphohistiocytic or lichenoid infiltrates in the dermis with pigmentary incontinence and presence of melanophages [4].

Although lichen planus pigmentosus was first described by Bhutani et al. [5] in Indians, it is also a common pigmentary disorder among other populations [5, 6]. Its exact pathogenesis is unknown. Hepatitis $\mathrm{C}$ virus [3], mustard oil, amla oil, henna and hair dye [6] could be precipitating factors in predisposed individuals. The association between hepatitis $\mathrm{C}$ virus and lichen planus has been extensively reviewed and the results suggest that lichen planus, mainly the oral type, is significantly associated with hepatitis $C$ virus infection in certain geographic areas [7]. Regarding lichen planus pigmentosus, the prevalence of positive serology for hepatitis $C$ virus is $60.6 \%$ in one study [3]. However, it would be difficult to conclude that there is a positive association between the two conditions in regions with a high prevalence of hepatitis $\mathrm{C}$ virus infection. Considerations in the differential diagnosis include linear ashy dermatosis, lichen striatus, linear and whorled nevoid hypermelanosis, and incontinentia pigmenti. Most of these can be differentiated by clinical findings and histopathology.

In conclusion, we report a case of lichen planus pigmentosus and hepatitis $\mathrm{C}$ virus infection. This case is an unusual form of lichen planus pigmentosus. The linear bilateral involvement was interesting because it is the first reported case of this distribution. We propose that serology for hepatitis $\mathrm{C}$ virus and liver function test should be carried out in patients with lichen planus pigmentosus. 


\begin{tabular}{c|l|l|l}
$\begin{array}{c}\text { Case Reports in } \\
\text { Demillatology }\end{array}$ & $\begin{array}{l}\text { Case Rep Dermatol 2010;2:169-172 } \\
\text { DOI: } 10.1159 / 000320775\end{array}$ & $\begin{array}{l}\text { Published online: } \\
\text { September 11, 201010 }\end{array}$ & $\begin{array}{l}\text { O 2010 S. Karger AG, Basel } \\
\text { ISSN 1662-6567 } \\
\text { www.karger.com/cde }\end{array}$ \\
\hline
\end{tabular}

\section{Conflicts of Interest}

The authors declare that they have no conflicts of interest.

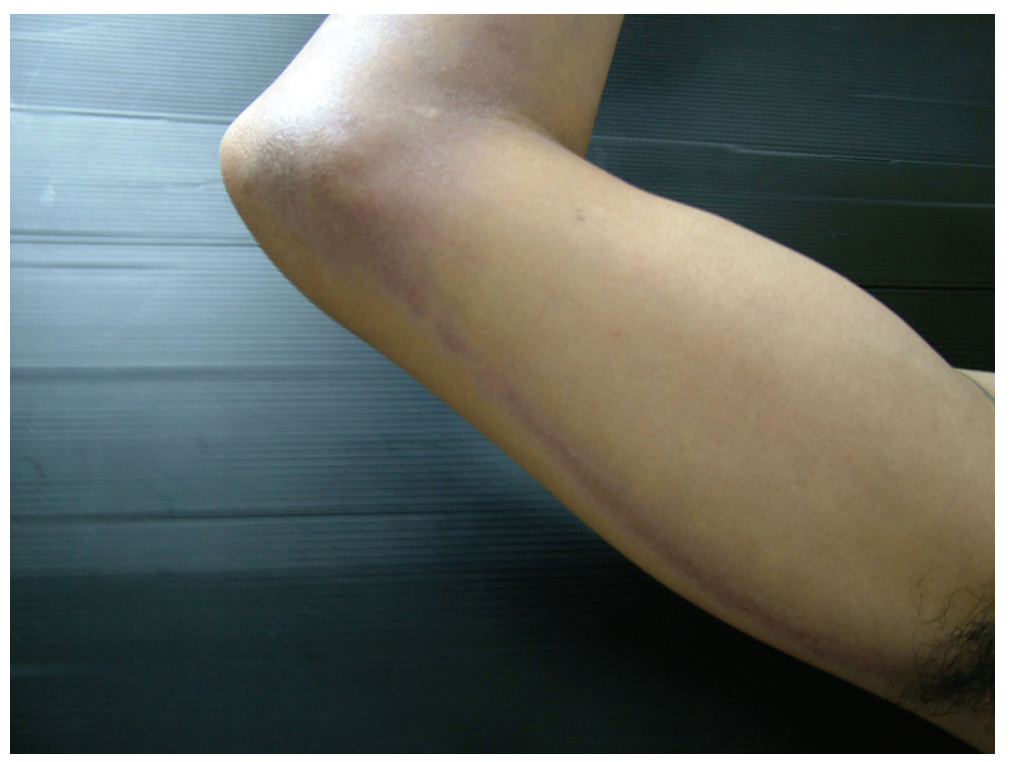

Fig. 1. Linear brown-gray streak with violaceous hue on the right arm and forearm.

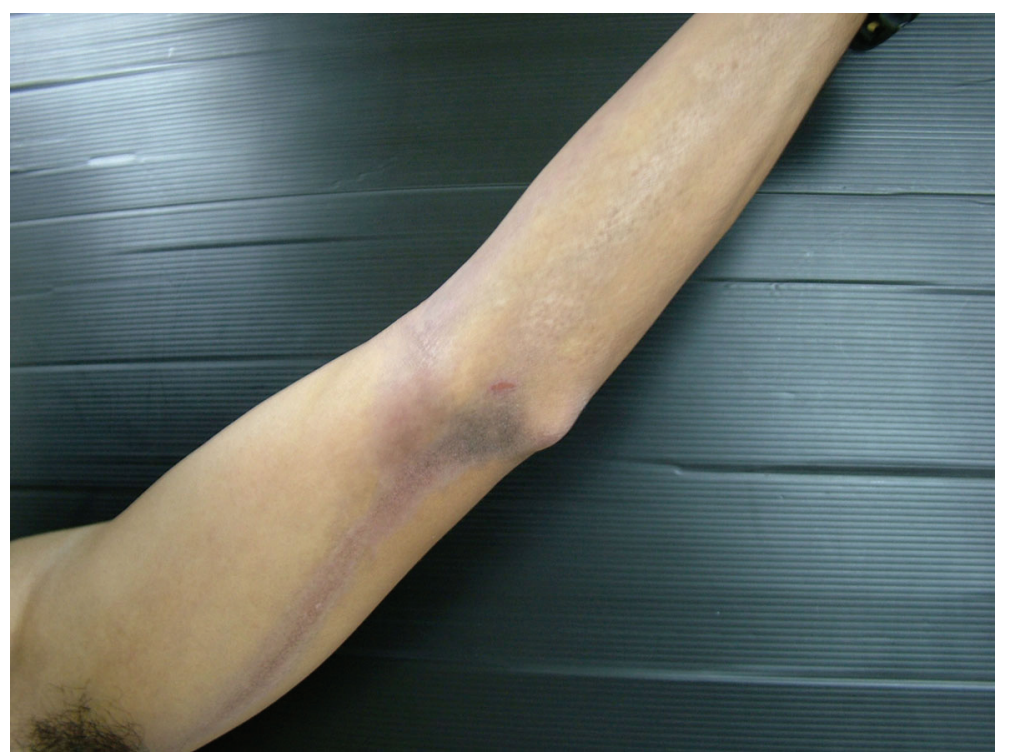

Fig. 2. Linear brown-gray streak with violaceous hue on the left arm and forearm. 


\begin{tabular}{c|l|l|l}
$\begin{array}{c}\text { Case Reports in } \\
\text { Demillatology }\end{array}$ & $\begin{array}{l}\text { Case Rep Dermatol 2010;2:169-172 } \\
\text { DOI: } 10.1159 / 000320775\end{array}$ & $\begin{array}{l}\text { Published online: } \\
\text { September 11, 201010 }\end{array}$ & $\begin{array}{l}\text { O 2010 S. Karger AG, Basel } \\
\text { ISSN 1662-6567 } \\
\text { www.karger.com/cde }\end{array}$ \\
\hline
\end{tabular}

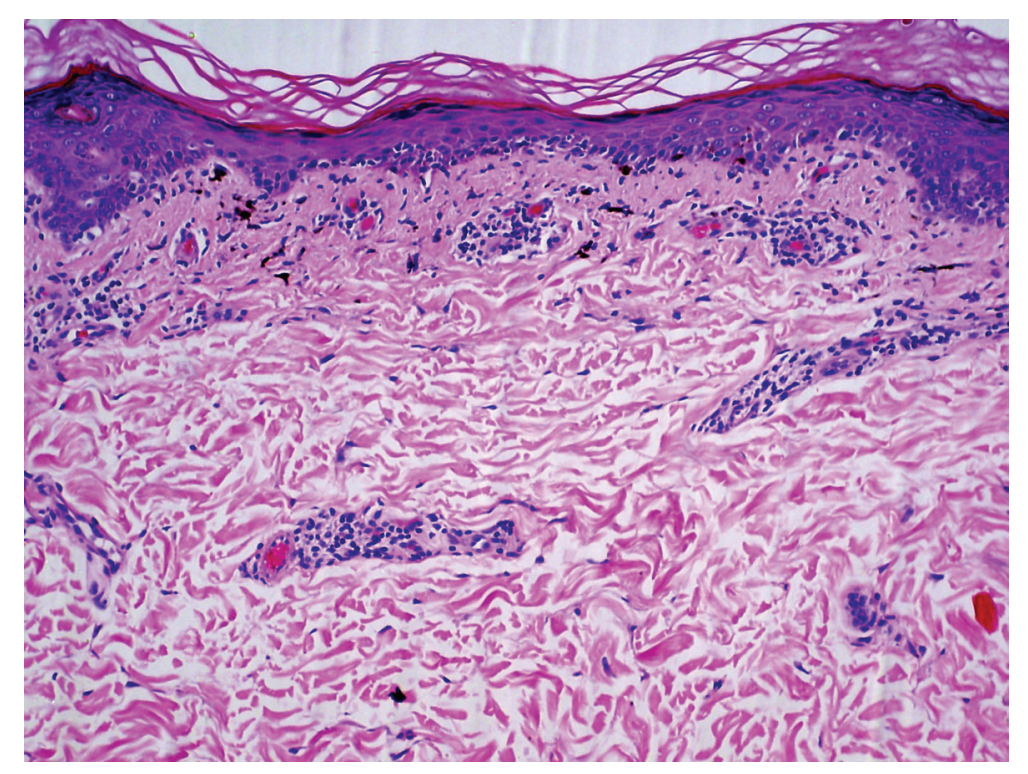

Fig. 3. Hematoxylin and eosin-stained slide, $\times 100$. Orthokeratosis, epidermal atrophy and focal hypergranulosis with vacuolar alteration of the basal cell layer and band-like infiltration of lymphocytes and melanophages.

\section{References}

1 Vega ME, Waxtein L, Arenas R, Hojyo T, Dominguez-Soto L: Ashy dermatosis and lichen planus pigmentosus: a clinicopathologic study of 31 cases. Int J Dermatol 1992;31:90-94.

2 Pock L, Jelínková L, Drlík L, Abrhámová S, Vojtechovská S, Sezemská D, Borodácová I, Hercogová J: Lichen planus pigmentosus-inversus. J Eur Acad Dermatol Venereol 2001;15:452-454.

3 Al-Mutairi N, El-Khalawany M: Clinicopathological characteristics of lichen planus pigmentosus and its response to tacrolimus ointment: an open label, non-randomized, prospective study. J Eur Acad Dermatol Venereol 2010;24:535-540.

4 Kanwar AJ, Dogra S, Handa S, Parsad D, Radotra BD: A study of 124 Indian patients with lichen planus pigmentosus. Clin Exp Dermatol 2003;28:481-485.

5 Bhutani LK, Bedi TR, Pandihi RK, Nayak NC: Lichen planus pigmentosus. Dermatologica 1974;149:43-50.

6 Kanwar AJ, Kaur S: Lichen planus pigmentosus. J Am Acad Dermatol 1989;21:815.

7 Carrozzo M, Pellicano R: Lichen planus and hepatitis $C$ virus infection: an updated critical review. Minerva Gastroenterol Dietol 2008;54:65-74. 